\title{
Analyzing the intention of the households to drop off mobile phones to the collection boxes: empirical study in Malaysia
}

Analyzing the intention of the households

\author{
Rafia Afroz
}

Department of Economics, Kulliyyah of Economics, International Islamic University Malaysia, Kuala Lumpur, Malaysia, and

Mohammad Muhibbullah, Puteri Farhana and Mohammad Niaz Morshed

Department of Economics, Kuliyyah of Economics and Management Sciences, International Islamic University Malaysia, Kuala Lumpur, Malaysia

\begin{abstract}
Purpose - To achieve proper waste management, the disposal of electronic waste (e-waste) is one suitable method. Most developing countries, including Malaysia, are facing lack of e-waste recycling facilities and low household participation. Using a survey method using a questionnaire, this study aims to examine the intention of Malaysian households to drop-off their mobile phones to the nearest collection boxes $(n=600)$.

Design/methodology/approach - This study expanded the theory of planned behavior by adding environmental awareness and knowledge. In addition, the cost of disposal and the convenience of the available disposal infrastructure were measured as two parts of the perceived behavioral control.

Findings - The results of this study show that environmental knowledge and awareness have a significant impact on attitudes toward recycling intention of the households. In addition, it was also found that the attitude and cost of disposal infrastructure is positively related to household intention.

Originality/value - These results show that if e-waste collection boxes are provided to the nearest community and e-waste management information is distributed, this will increase household participation in e-waste management.
\end{abstract}

Keywords Theory of planned behavior (TPB), Structural equation modeling (SEM), Mobile phone, E-waste recycling

Paper type Research paper

(C) Rafia Afroz, Mohammad Muhibbullah, Puteri Farhana and Mohammad Niaz Morshed. Published in Ecofeminism and Climate Change. Published by Emerald Publishing Limited. This article is published under the Creative Commons Attribution (CC BY 4.0) licence. Anyone may reproduce, distribute, translate and create derivative works of this article (for both commercial and noncommercial purposes), subject to full attribution to the original publication and authors. The full terms of this licence may be seen at http://creativecommons.org/licences/by/4.0/legalcode

The authors would like to acknowledge the Research Initiative Grant Scheme (publication), for funding of "Digital development, Economics Growth. Environmental Sustainability and Population Health in Malaysia: Applying Response Surfaces for the F-test of cointegration model" (Ref: PRIGS18-006-0006).

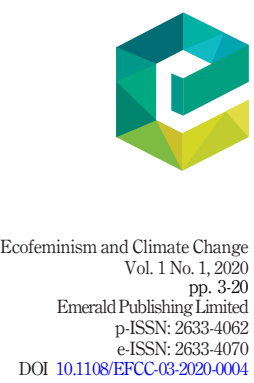

Received 10 January 2020 Revised 5 March 2020 Accepted 10 March 2020 


\section{EFCC}

1,1

\section{Introduction}

All countries together produced $6.1 \mathrm{~kg}$ per capita ( $\mathrm{kg} / \mathrm{inch}$ ) of electronic waste (e-waste) per year in 2016, compared with $5.8 \mathrm{~kg} /$ inch created in 2014. It is predicted that the amount of ewaste will increase to $6.8 \mathrm{~kg} / \mathrm{inch}$ by 2021. In 2016, Asia generated the largest volume of ewaste (18.2 million tons), followed by Europe (12.3 million tons), America (11.3 million tons), Africa (2.2 million tons) and Oceania (0.7 million tons). E-waste has become significant waste in Malaysia since 2012. In 2014, e-waste accounted for $4.5 \%$ of the total waste generation schedule (Jamin and Mahmood, 2015). The total amount of e-waste generated was about 77 kilotons in 2017 (Baldé et al., 2017) and $7.6 \mathrm{~kg}$ per person in 2016 (StEP (Solving the e-waste problem), 2018). Between 2015 and 2017, an increase (60.3\%) in e-waste was observed in the industrial sector (DOE, 2015a, 2015b, 2015c, 2017). According to forecasts, in 2020, the volume of e-waste will be 10 million tons, and annual progress will be $14 \%$, and this is believed to be because of televisions and mobile phones (Shumon et al., 2014).

The initial stage of e-waste processing causes significant damage to the health of garbage collectors, workers without personal protective equipment and the environment. In Malaysia, the Department of the Environment (DOE) has provided rules and regulations for the disposal of e-waste. A recycling policy is very important because of scare resources and proper waste management system (Oguchi et al., 2013). It is also inevitable that recycling can reduce greenhouse gas emissions, save energy and materials, reduce human health impacts and increase job creation (Hotta et al., 2014). Consequently, these rules do not provide any data on the current nature of technological waste, practice and economic conditions, although the effective management of e-waste has a very significant impact on the ability to dispose of e-waste (Zeng et al., 2017). Thus, progress in e-waste management in Malaysia has not become attractive since 2010 (Kalana, 2010). Malaysia expects to become a technologically advanced country by 2020, and an effective e-waste management system is an important policy to achieve the 2020 goal, but it is still in its preliminary stages (Shumon et al., 2014). Malaysia does not have a systematic management of hazardous wastes for the transport and disposal of wastes, as well as law enforcement agencies (Nnorom and Osibanjo, 2008). Consequently, it is becoming increasingly necessary for governments to adopt specific legislation on e-waste and to develop integrated e-waste management systems to minimize these consequences of the improper disposal of such waste (Pariatamby and Victor, 2013).

Consequently, adequate knowledge is needed about consumer behavior regarding e-waste and about factors that will increase consumer intentions to participate in environmental behavior. Previous studies have shown that awareness of recycling, norms, availability of infrastructures and disposal services, housing conditions and economic benefits, information about the potential toxicity of e-waste and previous experience in recycling e-waste also influence the decision of the consumer whether they are going to recycle. In addition, some studies have found that gender and marital status are also a significant predictor of disposal behavior (Saphores et al., 2012; Wang et al., 2016; Wang et al., 2011a, 2011b).

The theory of planned behavior (TPB) model can be used to identify factors that influence households' decision on e-waste disposal because it is a very systematic, theoretically sound, successful and proven approach. Therefore, because of these advantages, many previous studies have recognized that TPB is very useful for identifying environmental factors (Yazdanpanah, 2016).

In addition, TPB is familiar because it has general applicability in explaining behavior on various topics, culture and society (Klöckner, 2015). For example, TPB has been used to 
explain pro-ecological behavior in various areas, such as tourism sustainability (Han et al., 2010), use of public transport (Heath and Gifford, 2002), energy use (Abrahamse and Steg, 2009) and water conservation (Lam, 2006). Moreover, in some cases, TPB has surpassed other decision models associated with this study. For example, Kaiser et al. (2005) and Aguilar-Luzón et al. (2012) showed that TPB surpasses the theory of norms of belief in value, which was first introduced by Stern et al. (1999) in predicting pro-ecological behavior. However, many studies analyze the determinants of processing behavior using the expanded TPB model, adding various constructs such as moral standards, convenience, infrastructure and a sense of duty (Wang et al., 2011a, 2011b; Nigbur et al., 2010; Ramayah et al., 2012; Yin et al., 2014; Kumar, 2017).

However, there is insufficient research in the scientific literature on household intentions to process and their participation in e-waste management in emerging markets. It is also noted that there are very few studies that examine the behavior of e-waste disposal among households in Malaysia using the extended TPB model. Thus, this study offers an understanding of the key determinants that influence households' intentions to abandon their mobile phones at a mobile phone collection center using an extended TPB model. The rest of this article is structured as follows: a discussion of e-waste management in Malaysia is provided in Section 2. A theoretical research model, hypothesis based on previous studies, data sources and research methods are presented in Section 3. The results of the study are discussed in Section 4. Finally, Section 5 summarizes the conclusions of this document and offers relevant policy recommendations.

\section{Electronic waste management in Malaysia}

\subsection{Electronic waste generation in Malaysia}

In Malaysia, the DOE describes e-waste as "wastes from the electrical and electronic assemblies containing components such as accumulators, mercury-switches, glass from cathode-ray tubes and other activated glass or polychlorinated biphenyl-capacitors, or contaminated with cadmium, mercury, lead, nickel, chromium, copper, lithium, silver, manganese or polychlorinated biphenyl's" (DOE, 2010). Mobile phones and mobile phone rechargeable batteries have been increasing at an alarming rate since 2008/2009.

\subsection{Collection of electronic waste initiatives in Malaysia}

To develop a more established household e-waste collection system, the Malaysian Ministry of Energy has worked with the Japan International Cooperation Agency to implement a household e-waste collection policy. In connection with this policy, they carried out various pilot projects in different places in Malaysia to collect very small amounts of e-waste from households, and most of the e-waste collected was washing machines (JICA, 2014; Shumon et al., 2014; Yong et al., 2019). In addition, the Department of Energy has established several collection points for household e-waste. The Alam Alliance e-waste recycling program (e.g. Senheng Electric) managed most collection points (DOE, 2015a, 2015b, 2015c; DOE, 2018a, 2018b, 2018c).

The Malaysian Communications and Multimedia Commission (MCMC) is an organization managed by the Ministry of Communications and Multimedia of Malaysia. The MCMC has installed its e-waste collection boxes at the nearest locations for its program participants. They are also trying to disseminate information about the devastating consequences of waste of electrical and electronic equipment improper disposal to encourage households to abandon their old mobile phones (MCMC, 2018a, 2018b; Otto et al., 2018). Telecommunications companies (e.g. Telco), schools/universities, retailers and corporate organizations are also involved in this program.
Analyzing the intention of the households 


\section{EFCC}

1,1

In addition to MCMC, two well-known mobile phone manufacturers, Nokia and Motorola, also distribute a limited amount of recycling facilities to users of their products. Nokia launched a waste management program called Nokia Kiosks in 2001. Under this program, they established collection points in only three cities of the country (Kuala Lumpur, Petaling Jaya and Puchong) (www.nokia.com.my/nokiakiosk). Another company, Motorola, provides seven collection points for users of its products to recycle their mobile phones as part of the ECOMOTO return program (www.motorola.com). It is reported on their website that information about these collection points is reported on their website.

In Malaysia, despite the growing trend of e-waste generation, households are not required to dispose of their e-waste in a recycling center (Yong et al., 2019). Although the MCMC and DOE are trying to implement various e-waste recycling programs, they are criticized that their programs are mainly focused on cities and urban areas. As a result, the impact of their initiatives is so small compared to the growing trend toward the production of mobile e-waste.

Malaysia lacks information on e-waste disposal. Kalana (2010) stated that $43 \%$ of household members in Shah Alam, Selangor, Malaysia, were unaware of e-waste, and most participants were not concerned about the correct ways to dispose of their household ewaste. Many households sincerely do not want to discard their e-waste, as they believe that garbage is still priceless (Wang et al., 2011a, 2011b; Shumon et al., 2014). Contrary to their results, Afroz et al. (2013) found that most Malaysian households (59 \%) from their Kuala Lumpur poll know the effects of e-waste on the environment and human health.

Some studies have shown that in some countries, such as Bangladesh and India, households do not want to dispose of their e-waste because they do not benefit if they recycle, and instead they have to pay e-waste recycling fees that can reduce their consumption revenue (Islam et al., 2016; Song et al., 2012), and in China, thanks to the availability of alternative models, consumers receive payment for the processing of e-waste (i.e. reverse logistics systems with automatic vending machines (Tong et al., 2018).

In addition, Babayemi et al. (2017) stated that only a few of the selected respondents in their study tend to store their old and used mobile phones in their homes, and later they simply dispose of them along with their ordinary household waste; while few of them bring their old phones to Dropbox, distributed by laptop makers such as Dell. In addition, informal e-waste collectors are desirable for households that use an official e-waste collection system. Thus, Malaysian regulators planned to provide incentive schemes to the general public when they return their electrical and electronic equipment (JICA, 2014), but these schemes have not yet been effectively implemented across the country.

\section{Literature review}

Correct knowledge of household behavior and the factors that influence recycling behavior can help create more efficient and faster recycling programs in society to increase household participation in recycling programs. Therefore, it is important to investigate and conduct empirical studies to identify the tools responsible for handling behavior (Pakpour et al., 2014; Kofoworola, 2007; Rahardyan et al., 2004; Wilkinson et al., 2007).

Although numerous studies related to behavioral inequality have been conducted to elucidate the factors that motivated behavior (Bakshan et al., 2017), the relationship between people's intentions and behavior is poorly defined in the literature. There are also some studies that explain indicators of how people try, what level of effort they plan and what problems directly affect their behavior (Ajzen, 1991). Consequently, an analytical method of decision-making from a microstructural point of view is desirable, which includes the 
Schwartz norm activation model (Van Liere and Dunlap, 1978), the theory of reasoned action (TRA) (Fishbein and Ajzen, 1980) and the TPB (Ajzen (1991).

\subsection{Theory of planned behavior}

Against this background, a clearly defined TPB is an extension of TRA, offers a theoretical basis for recognizing behavioral factors during processing (Oztekin et al., 2017) and is recognized as one of the most effective socio-psychological models that clarify behavior. TPB confirms that a person's intention is determined by three principles, including attitude, subjective norms and perceived behavioral control (Ajzen, 1993). "Attitude" means the degree to which a person evaluates behavior as satisfactory or unsatisfactory (Ajzen, 1991). "Subjective norms" are the result of the influence of external social characteristics on human behavior (Ajzen, 1991). "Perceived behavioral control" means for people an awareness of the ease of executing behavior (Ajzen, 1993) (Figure 1). In studying recycling intent, the importance of the TPB model is highly appreciated when comparing strong positive associations between the three abovementioned constructs and recycling behavior using path analysis (Chan and Bishop, 2013; Mak et al., 2019). The TPB model is shown in Figure 1.

In this study, the cost of recycling and the convenience of the available recycling infrastructure were measured as two parts of the proposed behavioral control variables, which were subsequently analyzed for household intentions to recycling. In addition to these variables, environmental knowledge and awareness are also taken into account, which are expected to stimulate the relationships.

\subsection{Previous studies on recycling behavior}

As studies of waste management behaviors are well thought out, it has been proven that TPB is a capable structure for identifying factors that influence people's behavior in recycling. For example, Kumar (2019) reported that respondent attitudes greatly inspire respondents to recycle their e-waste. Nixon and Saphores (2007) found that respondents' attitudes toward the environment greatly affected their willingness to pay advanced process fees for electronics.

Wang et al. (2016) reported that environmental awareness, attitudes toward recycling, the perception of informal recycling, revenues and recycling costs indirectly influenced the Chinese resident's intent on recycling e-waste. In another study also conducted in China, along with living conditions and economic benefits, the recycling habit and convenience of processing facilities and services were also two key additional precursors to the desire and behavior of Beijing residents to process e-waste (Wang et al., 2011a, 2011b). Echegaray and Hansstein (2017) also found that the majority of women, middle-aged and low-income people surveyed in Beijing are positive about e-waste processing. Nguyen et al. (2018) argued that inconvenience to recycling negatively impacted behavioral intentions of residents on recycling, and some studies have shown that inconvenience to recycling did not

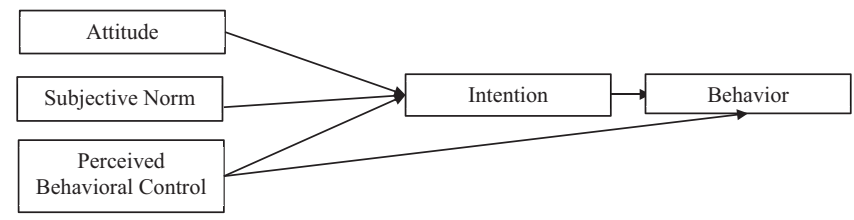

Figure 1.

Source: Ajzen (1991) 
EFCC

1,1

significantly affect behavioral intentions. A more recent study by Gonul Kochan et al. (2016) concluded that people are aware of the consequences of processing, the more they are involved in processing activities and the more they feel the convenience of recycling, the more they participate in processing. More recently, Han et al. (2010) conducted a study on plastics processing in Pakistan. The results of their research show that subjective norms, awareness of the consequences and convenience are the main predictors of the intention to return/process. In the same year, Wang et al. (2019) conducted an online study on the behavior of Chinese people for waste management. The results of their study show that perceived behavioral control, subjective norms, attitudes and economic motivation were positively and significantly related to online readiness. The conceptual basis of this study is shown in Figure 1.

Many studies acknowledged the empirical and theoretical relation ration between environmental knowledge and intention of the households to do recycling (Wang et al., 2016; Ramayah et al., 2012). Many researchers establish that accurate knowledge on disposal has very dominant effect on the recycling behavior of the households (Kelly et al., 2006). Moreover, several researchers also found that the households will participate more in recycling activities if they can receive more adequate knowledge about the importance of disposal, and how and where to dispose of it (Ramayah et al., 2012). Therefore, the following hypothesis was proposed:

H1. Environmental knowledge and awareness are positively associated with attitude.

Chan (1998) reported that respondent attitudes determine their behavior. If a person is positive, he will be engaged in recycling, because he believes that if he disposes of e-waste, this will reduce environmental damage, increase the proper use of landfills and preserve the ecological environment. A study of the behavior of processors in Malaysia (Ramayah et al., 2016) found that attitudes are an important predictor of the behavior of processors. Many studies have reported a positive and significant effect of attitudes on human behavior (Masud et al., 2015; Afroz et al., 2013). In contrast, some studies also report that attitudes do not significantly affect intention (Dixit and Badgaiyan, 2016; Lizin et al., 2017; Wan et al., 2014). Based on the literature sought in this study, the following hypothesis was put forward:

H2. The attitude is positively related to disposal behavior.

Existing research on behavior related to processing emphasizes that social norm is a critical factor. Singh et al. (2018) denote a subjective norm as a mixture of prohibitive and descriptive norms that follow the perception of satisfactory/unsatisfactory behavior by interactive relationships and neighboring societies. Many researchers report that household subjective norms and intentions were significantly and positively related (Echegaray and Hansstein, 2017; Lizin et al., 2017). Based on these views, the following was suggested:

\section{H3. Subjective norms are positively associated with processing behavior.}

Many literary sources have found that the inconvenience and cost of disposal separately affects household behavior during disposal. For this reason, it is proposed to classify these two elements as two parts of perceived behavior control (Wang et al. (2016); Ramayah et al., 2012). Convenience is an essential component of stimulating behavior during processing (Gonul Kochan et al., 2016). In previous studies, it was found that people most often go to landfills when they make recycling available (Sidique et al., 2010). If there are difficulties in storing waste and creating more places for collecting items to be recycled (Gonul Kochan et al., 2016), households will be more motivated to participate in recycling activities. 
Therefore, many studies show that convenience is associated with the intention of recycling (Wang et al., 2015; Chen and Tung, 2010; Bezzina and Dimech, 2011). Thus, the evidence presented created the following hypothesis:

H4. Convenience of available recycling infrastructure is positively related to recycling behavior.

Diekmann and Preisendörfer (2003) put forward two hypotheses about the cost of disposal: low cost of disposal and high cost of disposal. They explained that psychological factors have different effects on behavior that is relatively less costly (low cost) compared to behavior that is more expensive (expensive). In fact, the cost of disposal depends on how people perceive the situation. Proposed to include the available time, distance, space and ease of processing operations for items of processing costs. Therefore, based on the literature, we propose:

H5. Cost of recycling is positively related to recycling behavior.

Figure 2 shows the extended TPB model that has been used in this study to test the hypotheses.

\subsection{Methodology}

The survey was conducted from January to April 2018. All respondents were owners of mobile phones and laptops. The issue of adequacy of sample size remains the main problem in the application of structural equation modeling (SEM). To obtain sample size, this study uses the most widely used formula presented by Yamana (1967), which is given below:

$$
n=\frac{N}{1+N(e)^{2}}
$$

where:

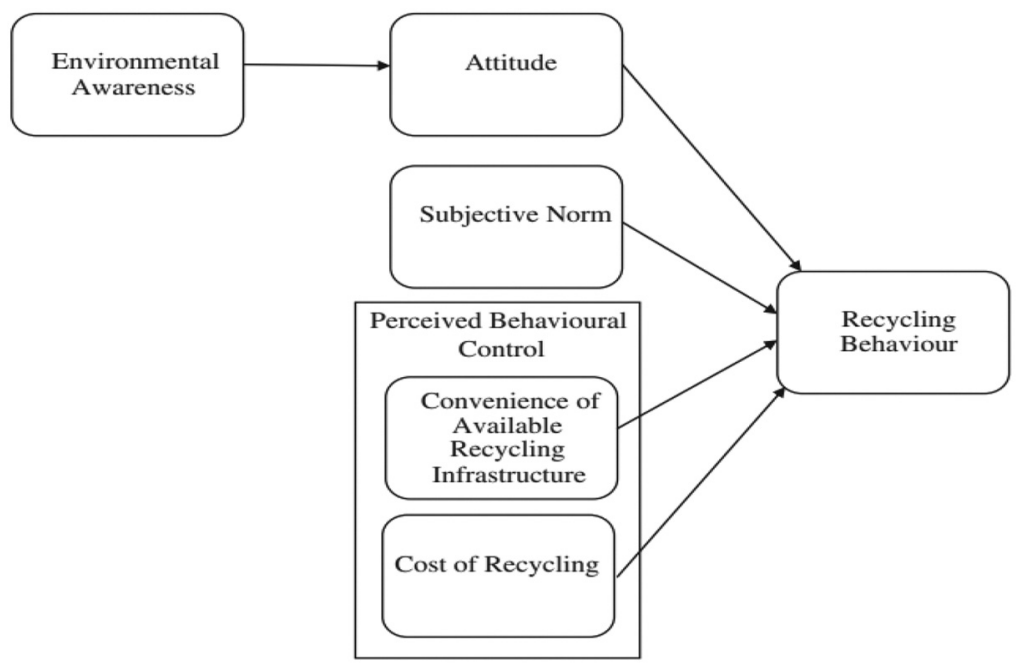

Analyzing the intention of the households

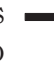


EFCC

1,1

$n=$ desired sample size;

$\mathrm{N}=$ the population size (7.2 million); and

$e=$ level of precision or sampling error (sampling error in this study is $5 \%$ ).

Based on the above formula, the required sample size required in this study is 399.77 . Thus, it is considered equal to 400 . It is calculated with a $95 \%$ confidence level and a $5 \%$ error rate. Data for this study were obtained from five different locations in the Klang Valley, including Shah Alam, Pekeling, Cheras, Gombak and Bandar-Tasik-Selatan. A total of 600 samples were randomly selected, and household heads were interviewed face-to-face. Of the 600 distributed questionnaires, 525 questionnaires were used to analyze the study. The questionnaire used in the survey of this study was compiled in two languages (English and Malay). The questionnaire consists of two sections. The first section includes issues related to the socio-economic conditions of households. The second section contains questions that were used to evaluate several elements of all the different TPB constructs (Table 1). The dependent variable was the intention of households to recycle. All responses were rated on a five-point Likert scale with $1=$ strongly disagree and $5=$ strongly agree.

\subsection{Statistical analysis techniques}

SEM (AMOS version 16) is used to establish the model. The maximum likelihood estimation was used in this study (Jöreskog and Sörbom, 1996). The SEM was analyzed using two-step procedures (Byrne, 2013; Anderson and Gerbing, 1988). First, we completed the confirmatory factor analysis (CFA) to confirm the reliability, convergent and divergent validity. Second, we completed the hypothesis testing to investigate the causal relationships between the latent variables. The method of maximum likelihood estimation was performed on each stage as suggested by Byrne (2001).

\section{Analysis and results}

\subsection{Convergent validity}

The CFA results presented in Table 4 shows that all the latent constructs have the composite reliability values of at least 0.70 and average variance error (AVE) of at least 0.50 , it can be decided that the measurement model has an adequate convergent validity level (Table 2).

\subsection{Discriminant validity}

The results, as reported in Table 3, showed that the values in the rows and column of the table are smaller than the square root of AVE in the diagonal which confirms the discriminant validity of the model. So, it can be concluded that the model has adequate reliability, convergent validity and discriminant validity.

\subsection{Structural model results}

The hypothesis of the study was examined by conducting the structural model when the validity and reliability of the model is confirmed. Figure 3 shows the causative associations and fit indicators for the structural model. Figure 3 demonstrates that the value of $\lambda^{2} / d f$ for measurement model is 2.845 . The value of adjusted good of fit indicator is 0.860 . The values of normed fit index or Tucker Lewis index and comparative fit index are 0.920 and 0.930 , correspondingly. Moreover, value of root mean square error approximation is 0.069. The outcomes of the model confirm that it can efficiently reproduce the covariance matrix. 


\begin{tabular}{|c|c|c|c|}
\hline Attitude & $\begin{array}{l}\text { E-waste recycling is enjoyable (Att1) } \\
\text { E-waste recycling is decent (Att2) } \\
\text { E-waste recycling is accountable (Att3) } \\
\text { E-waste recycling is helpful (Att4) } \\
\text { E-waste recycling is relaxed (Att5) }\end{array}$ & $\begin{array}{l}\text { Kumar (2019), Oskamp et al. } \\
\text { (1991), Cheung et al. (1999), } \\
\text { Tonglet et al. (2004) }\end{array}$ & $\begin{array}{l}\text { Analyzing the } \\
\text { intention of the } \\
\text { households }\end{array}$ \\
\hline \multirow[t]{2}{*}{ Subjective norm } & \multirow{2}{*}{$\begin{array}{l}\text { I think that most of the people who are } \\
\text { significant to me should participate in the } \\
\text { recycling of e-waste (SN1) } \\
\text { My friends/peers anticipate me to recycle } \\
\text { (SN2) } \\
\text { Most people who matter to me would } \\
\text { support my recycling of e-waste (SN3) } \\
\text { Specialists expect me to recycle (SN4) }\end{array}$} & \multirow[t]{2}{*}{$\begin{array}{l}\text { Ajzen (2002), Tonglet et al. } \\
\text { (2004), Kumar (2019) }\end{array}$} & \\
\hline & & & \\
\hline \multirow{2}{*}{$\begin{array}{l}\text { Environmental-related } \\
\text { knowledge and } \\
\text { awareness }\end{array}$} & $\begin{array}{l}\text { Recycling is a main method to decrease } \\
\text { pollution (EW1) }\end{array}$ & \multirow[t]{2}{*}{$\begin{array}{l}\text { Ramayah et al. (2016), Kelly } \\
\text { et al. (2006), Wang et al. (2016) }\end{array}$} & \\
\hline & $\begin{array}{l}\text { Recycling is a main method to decrease } \\
\text { extravagant usage of dumping site (EW2) } \\
\text { Recycling is a main method to preserve } \\
\text { natural environment (EW3) }\end{array}$ & & \\
\hline \multirow[t]{2}{*}{$\begin{array}{l}\text { Convenience of available } \\
\text { recycling infrastructure }\end{array}$} & $\begin{array}{l}\text { I am used to drop off my mobile phone into } \\
\text { the collection boxes in my area (CRI1) } \\
\text { There are enough collection boxes of mobile } \\
\text { phones in my area (CRI2) }\end{array}$ & \multirow[t]{2}{*}{$\begin{array}{l}\text { Ramayah et al. (2016), Wang } \\
\text { et al. (2012), Chen and Tung } \\
\text { (2010), Bezzina and Dimech } \\
\text { (2011) }\end{array}$} & \\
\hline & $\begin{array}{l}\text { I trust that there are enough websites in } \\
\text { Malaysia that will support to decrease the } \\
\text { pollution to the environment (CRI3) }\end{array}$ & & \\
\hline \multirow[t]{3}{*}{ Cost of recycling } & $\begin{array}{l}\text { E-waste recycling is an relaxed task for me } \\
\text { (CR1) }\end{array}$ & \multirow{3}{*}{$\begin{array}{l}\text { Ramayah et al. (2016), Wang } \\
\text { et al. (2012), Chen and Tung } \\
\text { (2010), Bezzina and Dimech } \\
\text { (2011), Sidique } \text { et al. (2010) }\end{array}$} & \\
\hline & $\begin{array}{l}\text { There are sufficient place in my house to } \\
\text { stock the e-waste (CR2) }\end{array}$ & & \\
\hline & $\begin{array}{l}\text { I have sufficient time to sort the e-waste and } \\
\text { other waste for purpose of recycling (CR3) }\end{array}$ & & \\
\hline \multirow[t]{3}{*}{ Intention to recycle } & $\begin{array}{l}\text { My intention is to make strategies to recycle } \\
\text { e-waste frequently (IN1) }\end{array}$ & \multirow[t]{3}{*}{$\begin{array}{l}\text { Holland et al. (2006), Kumar } \\
\text { (2019) }\end{array}$} & \\
\hline & My intention is to recycle e-waste (IN2) & & \\
\hline & $\begin{array}{l}\text { My intention is to put additional } \\
\text { determination into recycling e-waste (IN3) }\end{array}$ & & construc \\
\hline
\end{tabular}

Table 4 shows the summary of the measurement model. The value of $R^{2}$ is 0.79 , which describes that the independent variables explained $79 \%$ of the discrepancy in intention of the households. The results of hypothesis testing demonstrate that the coefficient of environment awareness is 0.30 and it affects attitude positively and significantly at $1 \%$ level of significance. This result is consistent with other studies who also prove that knowledge of the individuals about the recycling scheme is a significant and positive determinants of the attitude of the individuals (Kelly et al., 2006; Ramayah et al., 2012). But this was not proved true in a recent study conducted by Noordin and Sulaiman, (2010) on environmental awareness among secondary students in Malaysia. They found that although the students are aware of environment, they find it hard to make their own environment better.

In this study, the coefficients of attitude and convenience of available recycling infrastructure are 0.08 and 0.56 , respectively. Both of the variables positively and significantly affect intention of the households to drop off their mobile phones at $1 \%$ level of significance. Furthermore, subjective norm $(\beta=0.09, p>0.05)$ and cost of recycling $(\beta=$ 


\begin{tabular}{|c|c|c|c|c|c|c|c|}
\hline $\begin{array}{l}\mathrm{EFCC} \\
1,1\end{array}$ & Variable & Item & $\begin{array}{l}\text { Corrected item-to-total } \\
\text { correlation }\end{array}$ & $\begin{array}{c}\text { Cronbach's } \\
\alpha\end{array}$ & $\begin{array}{c}\text { Factor loading } \\
\lambda\end{array}$ & AVE & $\begin{array}{l}\text { Composite } \\
\text { reliability }\end{array}$ \\
\hline \multirow{18}{*}{12} & \multirow[t]{5}{*}{ Attitude } & Att1 & 0.929 & \multirow[t]{5}{*}{0.938} & 0.815 & \multirow[t]{5}{*}{0.739} & \multirow[t]{5}{*}{0.825} \\
\hline & & Att2 & 0.923 & & 0.856 & & \\
\hline & & Att3 & 0.915 & & 0.908 & & \\
\hline & & Att4 & 0.919 & & 0.876 & & \\
\hline & & Att5 & 0.921 & & 0.871 & & \\
\hline & \multirow[t]{4}{*}{ Subjective norm } & SN1 & 0.708 & \multirow[t]{4}{*}{0.766} & 0.746 & \multirow[t]{4}{*}{0.540} & \multirow[t]{4}{*}{0.939} \\
\hline & & SN2 & 0.711 & & 0.753 & & \\
\hline & & SN3 & 0.711 & & 0.712 & & \\
\hline & & SN4 & 0.789 & & & & \\
\hline & \multirow{9}{*}{$\begin{array}{l}\text { Environmental- } \\
\text { related knowledge } \\
\text { and awareness } \\
\text { Convenience of } \\
\text { available recycling } \\
\text { infrastructure } \\
\text { Cost of recycling }\end{array}$} & EW1 & 0.858 & \multirow[t]{3}{*}{0.891} & 0.892 & \multirow[t]{3}{*}{0.716} & \multirow[t]{3}{*}{0.882} \\
\hline & & EW2 & 0.848 & & 0.904 & & \\
\hline & & EW3 & 0.861 & & 0.731 & & \\
\hline & & CRI1 & 0.780 & \multirow[t]{3}{*}{0.834} & 0.832 & \multirow[t]{3}{*}{0.607} & \multirow[t]{3}{*}{0.822} \\
\hline & & CRI2 & 0.785 & & 0.753 & & \\
\hline & & CRI3 & 0.781 & & 0.780 & & \\
\hline & & CR1 & 0.938 & \multirow[t]{3}{*}{0.944} & 0.740 & \multirow[t]{3}{*}{0.611} & \multirow[t]{3}{*}{0.825} \\
\hline & & $\mathrm{CR} 2$ & 0.927 & & 0.741 & & \\
\hline & & CR3 & 0.926 & & 0.813 & & \\
\hline & \multirow[t]{3}{*}{ Intention to recycle } & IN1 & 0.935 & \multirow[t]{3}{*}{0.939} & 0.784 & \multirow[t]{3}{*}{0.755} & \multirow[t]{3}{*}{0.939} \\
\hline Ta & & IN2 & 0.920 & & 0.877 & & \\
\hline The results of CFA & & IN3 & 0.919 & & 0.917 & & \\
\hline
\end{tabular}

$0.09, p>0.05)$ are not important factors of recycling intention. The previous studies also show that subjective norm does not have significant impact on recycling intention (Dixit and Badgaiyan, 2016; Lizin et al., 2017; Wan et al., 2014; Ghani et al., 2013). Thus, the results of the hypotheses testing follow H1, H2 and $H 4$ and they do not follow $H 3$ and $H 5$. Convenience of recycling infrastructure has the largest coefficient followed by attitude of the individual.

Surprisingly, the results also revealed that coefficient of the costs of recycling is positive but it is not significant. It is in discrepancy with the results from some of the previous studies. For example, Ramayah et al. (2012) found that although cost of recycling is not a significant predictor of recycling behavior but it has negative association with the intention of recycling. However, Nguyen et al. (2018) reported that in the case of Vietnam, people are more concern about their health than their expenditure they have to spend on recycling

Table 3.

Discriminant validity

\begin{tabular}{lcccccccccc}
\hline & CR & ATT & SN & EW & CRI & INT & Minimum & Maximum & Mean & SD \\
\hline CR & 0.782 & & & & & & 1 & 5 & 3.45 & 0.932 \\
ATT & 0.203 & 0.866 & & & & & 1 & 5 & 2.41 & 0.954 \\
SN & 0.226 & 0.455 & 0.735 & & & & 1 & 5 & 2.66 & 0.981 \\
EW & 0.169 & 0.249 & 0.205 & 0.846 & & & 1 & 5 & 3.89 & 0.727 \\
CRI & 0.233 & 0.241 & 0.322 & 0.663 & 0.779 & & 1 & 5 & 4.00 & 0.645 \\
INT & 0.233 & 0.235 & 0.292 & 0.528 & 0.575 & 0.869 & 1 & 5 & 4.03 & 0.710
\end{tabular}
and descriptive analysis

Notes: $\mathrm{CR}=$ cost of recycling; $\mathrm{ATT}=$ attitude; $\mathrm{SN}=$ subjective norm; $\mathrm{EW}=$ environmental knowledge; $\mathrm{CRI}=$ convenience of recycling infrastructure; INT = intention to recycle 


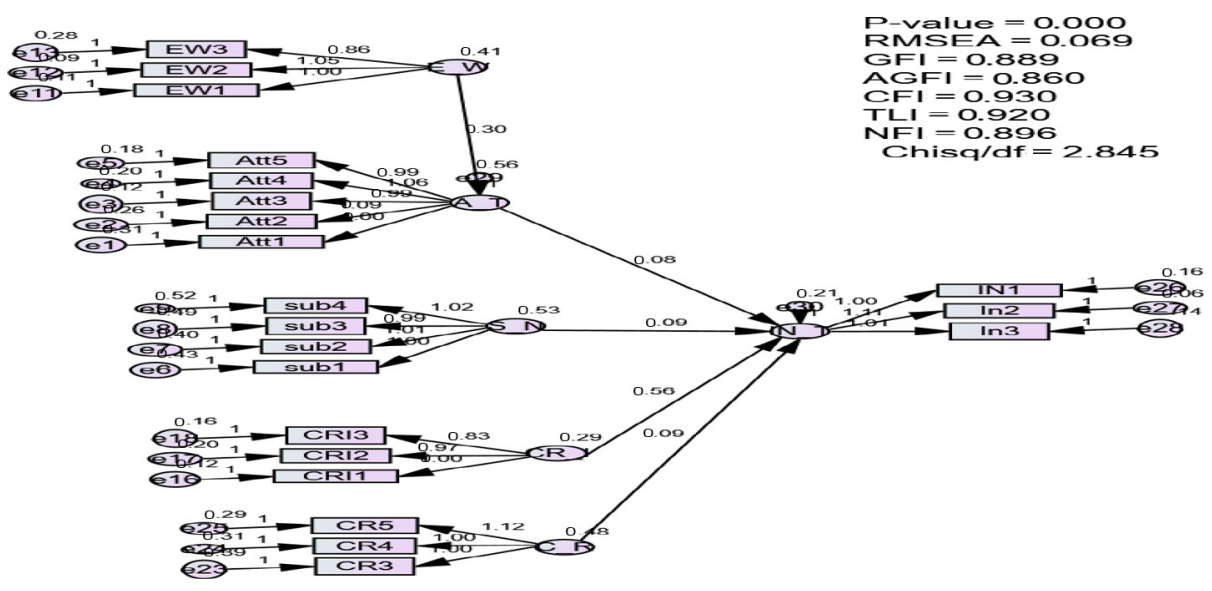

Analyzing the intention of the households

e-waste. This idea is also supported by the strong relationship between the awareness and recycling intention as analyzed above. When citizens are well aware of the risks associated with toxins in e-waste, they tend to pay more attention to protecting their health and are willing to participate in the recycling of e-waste, despite the costs they have to pay. This suggests that cost is not a big problem for residents when they agree to join in recycling activities.

\section{Discussion, conclusion and recommendations}

This study used an extended TPB to provide a better understanding of how attitudes, subjective norms and perceived behavioral control influence households in the Klang Valley to drop-off their mobile phones to the nearest collection points. Obviously, examining the behavioral intentions for e-waste disposal is extremely important, which is considered an important milestone and provides a solid foundation for the success of e-waste management in a developing country like Malaysia. Especially, in the context of the rapidly growing amount of e-waste, while current e-waste legislation is not very effective.

The results of this study show that environmental knowledge and awareness have a significant impact on attitudes toward recycling intention of the households. In addition, it was also found that the attitude and cost of disposal infrastructure is positively related to household intention. To raise household awareness, adequate information must be provided on the advantage of recycling e-waste and the location, method and incentive for e-waste

\begin{tabular}{llcll}
\hline Path & Hypothesis & Path coefficient & $t$-value & \multicolumn{1}{c}{ Results } \\
\hline EA $\rightarrow$ ATT & $H 1$ & 0.30 & $4.562^{* *}$ & Supported \\
ATT $\rightarrow$ INT & $H 2$ & 0.08 & $3.269^{* *}$ & Supported \\
SN $\rightarrow$ INT & $H 3$ & 0.09 & 1.345 & Not Supported \\
CRI $\rightarrow$ INT & $H 4$ & 0.56 & $9.205^{* *}$ & Supported \\
CR $\rightarrow$ INT & $H 5$ & 0.08 & 1.456 & Not supported \\
$R^{2}=0.79$ & & & &
\end{tabular}

Notes: $\mathrm{CR}=$ cost of recycling; $\mathrm{ATT}=$ attitude; $\mathrm{SN}=$ subjective norm; $\mathrm{EW}=$ environmental, knowledge; $\mathrm{CRI}=$ convenience of recycling infrastructure; $\mathrm{INT}=$ intention to recycle. $* * p<0.01$ and $* p<0.05$

Table 4. Summary of the structural model
Figure 3. The structural model 

study showed that to raise awareness, the government should deliver additional facts on e-waste management in formal and informal classes and seminars. In addition, it can be suggested that the manufacturer of mobile phones must deliver info on how to dispose of it and its significances, if not disposed of properly. For example, Nokia and Motorola could notify, disseminate and introduce recycling to the local population through betterunderstood advertising, promotions and channel more resources to recycling activities like those practiced in Taiwan (Chen and Tung, 2010).

\section{References}

Abrahamse, W. and Steg, L. (2009), "How do socio-demographic and psychological factors relate to households' direct and indirect energy use and savings?", Journal of Economic Psychology, Vol. 30 No. 5, pp. 711-720.

Afroz, R., Masud, M.M., Akhtar, R. and Duasa, J.B. (2013), "Survey and analysis of public knowledge, awareness and willingness to pay in Kuala Lumpur, Malaysia-a case study on household WEEE management", Journal of Cleaner Production, Vol. 52, pp. 185-193.

Aguilar-Luzón, M.D.C., García-Martínez, J.M.Á., Calvo-Salguero, A. and Salinas, J.M. (2012), "Comparative study between the theory of planned behavior and the value - belief-norm model regarding the environment, on Spanish housewives' recycling behavior", Journal of Applied Social Psychology, Vol. 42 No. 11, pp. 2797-2833.

Ajzen, I. (1991), "The theory of planned behavior", Organizational Behavior and Human Decision Processes, Vol. 50 No. 2, pp. 179-211.

Ajzen, I. (1993), "Attitude theory and the attitude-behavior relation", New Directions in Attitude Measurement, pp. 41-57.

Ajzen, I. (2002), Constructing a TPB Questionnaire: Conceptual and Methodological Considerations.

Anderson, J.C. and Gerbing, D.W. (1988), "Structural equation modeling in practice: a review and recommended two-step approach", Psychological Bulletin, Vol. 103 No. 3, p. 411.

Babayemi, J.O., Osibanjo, O. and Weber, R. (2017), "Material and substance flow analysis of mobile phones in Nigeria: a step for progressing e-waste management strategy", Journal of Material Cycles and Waste Management, Vol. 19 No. 2, pp. 731-742.

Bakshan, A., Srour, I., Chehab, G., El-Fadel, M. and Karaziwan, J. (2017), "Behavioral determinants towards enhancing construction waste management: a Bayesian network analysis", Resources, Conservation and Recycling, Vol. 117, pp. 274-284.

Baldé, C.P., Forti, V., Gray, V., Kuehr, R. and Stegmann, P. (2017), The Global e-Waste Monitor 2017: Quantities, Flows and Resources, United Nations University, International Telecommunication Union, and International Solid Waste Association.

Bezzina, F.H. and Dimech, S. (2011), "Investigating the determinants of recycling behaviour in Malta", Management of Environmental Quality: An International Journal, Vol. 22 No. 4, pp. 463-485.

Byrne, B.M. (2013), Structural Equation Modeling with EQS: Basic Concepts, Applications, and Programming, Routledge.

Chan, K. (1998), "Mass communication and pro-environmental behaviour: waste recycling in Hong Kong", Journal of Environmental Management, Vol. 52 No. 4, pp. 317-325.

Chan, L. and Bishop, B. (2013), "A moral basis for recycling: extending the theory of planned behaviour", Journal of Environmental Psychology, Vol. 36, pp. 96-102.

Chen, M.F. and Tung, P.J. (2010), "The moderating effect of perceived lack of facilities on consumers' recycling intentions", Environment and Behavior, Vol. 42 No. 6, pp. 824-844. 
Cheung, S.F., Chan, D.K.S. and Wong, Z.S.Y. (1999), "Reexamining the theory of planned behavior in understanding wastepaper recycling”, Environment and Behavior, Vol. 31 No. 5, pp. 587-612.

Chibunna, J.B., Siwar, C., Begum, R.A. and Mohamed, A.F. (2012), "The challenges of e-waste management among institutions: a case study of UKM", Procedia - Social and Behavioral Sciences, Vol. 59, pp. 644-649.

Diekmann, A. and Preisendörfer, P. (2003), "Green and greenback: the behavioral effects of environmental attitudes in low-cost and high-cost situations", Rationality and Society, Vol. 15 No. 4, pp. 441-472.

Dixit, S. and Badgaiyan, A.J. (2016), "Towards improved understanding of reverse logistics - examining mediating role of return intention", Resources, Conservation and Recycling, Vol. 107, pp. 115-128.

DOE (2010), Guidelines for the Classification of Used Electrical and Electronic Equipment in Malaysia, Malaysia, DOE, Kuala Lumpur.

DOE (2015a), Malaysia environmental quality report 2015, available at: https://enviro.doe.gov.my/ ekmc/digital-content/environmental-quality-report-2015/ (accessed 12 April 2018).

DOE (2015b), "Household e-waste", available at: www.doe.gov.my/hhew/e-waste-alam-alliance/ (accessed 05 October 2018).

DOE (2015c), "Household e-waste", available at: www.doe.gov.my/hhew/project-activities-2/ (accessed 05 October 2018).

DOE (2017), Malaysia environmental quality report 2017, Personal Communication, April 26, 2018.

DOE (2018a), "Household e-waste: collection points", available at: www.doe.gov.my/hhew/collectionpoints/ (accessed 05 October 2018).

DOE (2018b), "Household e-waste", available at: www.doe.gov.my/hhew/wpcontent/uploads/2017/11/ List-of-PP-Collection-Points.pdf (accessed 08 October 2018).

DOE (2018c), "E-waste Alam alliance Malaysia", available at: www.doe.gov.my/householdewaste/wpcontent/uploads/2015/10/Information-for-inclusion-in-the-DOE-Portal.pdf (accessed 05 October 2018).

Echegaray, F. and Hansstein, F.V. (2017), "Assessing the intention-behavior gap in electronic waste recycling: the case of Brazil”, Journal of Cleaner Production, Vol. 142, pp. 180-190.

Fishbein, M. and Ajzen, I. (1980), "Predicting and understanding consumer behavior: attitude-behavior correspondence", Understanding Attitudes and Predicting Social Behavior, pp. 148-172.

Ghani, W.A.W.A.K., Rusli, I.F., Biak, D.R.A. and Idris, A. (2013), "An application of the theory of planned behaviour to study the influencing factors of participation in source separation of food waste", Waste Management, Vol. 33 No. 5, pp. 1276-1281.

Gonul Kochan, C., Pourreza, S., Tran, H. and Prybutok, V.R. (2016), "Determinants and logistics of ewaste recycling”, The International Journal of Logistics Management, Vol. 27 No. 1, pp. 52-70.

Han, H., Hsu, L.T.J. and Sheu, C. (2010), "Application of the theory of planned behavior to green hotel choice: testing the effect of environmental friendly activities”, Tourism Management, Vol. 31 No. 3, pp. 325-334.

Heath, Y. and Gifford, R. (2002), "Extending the theory of planned behavior: predicting the use of public transportation 1", Journal of Applied Social Psychology, Vol. 32 No. 10, pp. 2154-2189.

Holland, R.W., Aarts, H. and Langendam, D. (2006), "Breaking and creating habits on the working floor: a field-experiment on the power of implementation intentions", Journal of Experimental Social Psychology, Vol. 42 No. 6, pp. 776-783.

Hotta, Y., Santo, A. and Tasaki, T. (2014), "EPR-Based electronic home appliance recycling system under home appliance recycling act of Japan”, Institute of Global Environmental Strategies, pp. 1-29.

Islam, M.T., Abdullah, A.B., Shahir, S.A., Kalam, M.A., Masjuki, H.H., Shumon, R. and Rashid, M. H. (2016), "A public survey on knowledge, awareness, attitude and willingness to pay for

Analyzing the intention of the households 
EFCC 1,1

WEEE management: case study in Bangladesh”, Journal of Cleaner Production, Vol. 137, pp. 728-740.

Jamin, N.C. and Mahmood, N.Z. (2015), "Scheduled waste management in Malaysia: an overview", Advanced Materials Research, Vol. 1113, p. 1113.

JICA (2014), Data collection survey on e-waste management in Malaysia and surrounding countries - Final report, available at: http://open_jicareport.jica.go.jp/pdf/12154589.pdf (accessed 25 August 2018).

Jöreskog, K.G. and Sörbom, D. (1996), LISREL 8: User's Reference Guide, Scientific Software International.

Kaiser, F.G., Hübner, G. and Bogner, F.X. (2005), "Contrasting the theory of planned behavior with the value-belief-norm model in explaining conservation behavior 1", Journal of Applied Social Psychology, Vol. 35 No. 10, pp. 2150-2170.

Kalana, J.A. (2010), "Electrical and electronic waste management practice by households in Shah Alam, Selangor, Malaysia”, International Journal of Environmental Sciences, Vol. 1 No. 2, pp. 132-144.

Kelly, T.C., Mason, I.G., Leiss, M.W. and Ganesh, S. (2006), "University community responses to oncampus resource recycling", Resources, Conservation and Recycling, Vol. 47 No. 1, pp. $42-55$.

Klöckner, C.A. (2015), The Psychology of Pro-Environmental Communication: Beyond Standard Information Strategies, Springer.

Kofoworola, O.F. (2007), "Recovery and recycling practices in municipal solid waste management in Lagos, Nigeria”, Waste Management, Vol. 27 No. 9, pp. 1139-1143.

Kumar, A. (2017), "Extended TPB model to understand consumer 'selling' behaviour: implications for reverse supply chain design of mobile phones", Asia Pacific Journal of Marketing and Logistics, Vol. 29 No. 4, pp. 721-742.

Kumar, A. (2019), "Exploring young adults'e-waste recycling behaviour using an extended theory of planned behaviour model: a cross-cultural study", Resources, Conservation and Recycling, Vol. 141, pp. 378-389.

Lam, S.P. (2006), "Predicting intention to save water: theory of planned behavior, response efficacy, vulnerability, and perceived efficiency of alternative solutions 1", Journal of Applied Social Psychology, Vol. 36 No. 11, pp. 2803-2824.

Lizin, S., Van Dael, M. and Van Passel, S. (2017), "Battery pack recycling: behaviour change interventions derived from an integrative theory of planned behaviour study", Resources, Conservation and Recycling, Vol. 122, pp. 66-82.

Mak, T.M., Iris, K.M., Wang, L., Hsu, S.C., Tsang, D.C., Li, C.N., Yeung, T.L., Zhang, R. and Poon, C.S. (2019), "Extended theory of planned behaviour for promoting construction waste recycling in Hong Kong", Waste Management, Vol. 83, pp. 161-170.

Masud, M.M., Akhtar, R., Afroz, R., Al-Amin, A.Q. and Kari, F.B. (2015), "Pro-environmental behavior and public understanding of climate change", Mitigation and Adaptation Strategies for Global Change, Vol. 20 No. 4, pp. 591-600.

MCMC (2018a), "MCMC's the mobile e-waste: 'old phone, new life' initiative. Personal communication”, May 16, 2018.

MCMC (2018b), "Location of mobile e-waste collection box", available at: https://mobileewaste.mcmc. gov.my/en-my/where-do-we-recycle\#section39 (accessed 05 October 2018).

Nguyen, T.N., Lobo, A. and Nguyen, B.K. (2018), "Young consumers' green purchase behaviour in an emerging market”, Journal of Strategic Marketing, Vol. 26 No. 7, pp. 583-600.

Nguyen, H.T.T., Hung, R.J., Lee, C.H. and Nguyen, H.T.T. (2018), "Determinants of residents' E-Waste recycling behavioral intention: a case study from Vietnam", Sustainability, Vol. 11 No. 1, pp. 1-24.

Nigbur, D., Lyons, E. and Uzzell, D. (2010), "Attitudes, norms, identity and environmental behaviour: using an expanded theory of planned behaviour to predict participation in a kerbside recycling programme", British Journal of Social Psychology, Vol. 49 No. 2, pp. 259-284. 
Nixon, H. and Saphores, J.D.M. (2007), "Financing electronic waste recycling Californian households' willingness to pay advanced recycling fees", Journal of Environmental Management, Vol. 84 No. 4, pp. 547-559.

Nnorom, I.C. and Osibanjo, O. (2008), "Overview of electronic waste (e-waste) management practices and legislations, and their poor applications in the developing countries", Resources, Conservation and Recycling, Vol. 52 No. 6, pp. 843-858.

Noordin, T.A. and Sulaiman, S. (2010), "The status on the level of environmental awareness in the concept of sustainable development amongst secondary school students", Procedia - Social and intention of the households Behavioral Sciences, Vol. 2 No. 2, pp. 1276-1280.

Oguchi, M., Sakanakura, H. and Terazono, A. (2013), "Toxic metals in WEEE: characterization and substance flow analysis in waste treatment processes", Science of the Total Environment, Vols 463/464, pp. 1124-1132.

Oskamp, S., Harrington, M.J., Edwards, T.C., Sherwood, D.L., Okuda, S.M. and Swanson, D.C. (1991), "Factors influencing household recycling behavior", Environment and Behavior, Vol. 23 No. 4, pp. 494-519.

Otto, S., Kibbe, A., Henn, L., Hentschke, L. and Kaiser, F.G. (2018), "The economy of E-waste collection at the individual level: a practice oriented approach of categorizing determinants of $\mathrm{E}$-waste collection into behavioral costs and motivation", Journal of Cleaner Production, Vol. 204, pp. 33-40.

Oztekin, C., Teksöz, G., Pamuk, S., Sahin, E. and Kilic, D.S. (2017), "Gender perspective on the factors predicting recycling behavior: implications from the theory of planned behavior", Waste Management, Vol. 62, pp. 290-302.

Pakpour, A.H., Zeidi, I.M., Emamjomeh, M.M., Asefzadeh, S. and Pearson, H. (2014), "Household waste behaviours among a community sample in Iran: an application of the theory of planned behaviour", Waste Management, Vol. 34 No. 6, pp. 980-986.

Pariatamby, A. and Victor, D. (2013), "Policy trends of e-waste management in Asia", Journal of Material Cycles and Waste Management, Vol. 15 No. 4, pp. 411-419.

Rahardyan, B., Matsuto, T., Kakuta, Y. and Tanaka, N. (2004), "Resident's concerns and attitudes towards solid waste management facilities", Waste Management, Vol. 24 No. 5, pp. 437-451.

Ramayah, T., Lee, J.W.C. and Lim, S. (2012), "Sustaining the environment through recycling: an empirical study”, Journal of Environmental Management, Vol. 102, pp. 141-147.

Ramayah, T., Ling, N.S., Taghizadeh, S.K. and Rahman, S.A. (2016), "Factors influencing SMEs website continuance intention in Malaysia", Telematics and Informatics, Vol. 33 No. 1, pp. 150-164.

Saphores, J.D.M., Ogunseitan, O.A. and Shapiro, A.A. (2012), "Willingness to engage in a proenvironmental behavior: an analysis of e-waste recycling based on a national survey of US households", Resources, Conservation and Recycling, Vol. 60, pp. 49-63.

Shumon, M.R.H., Ahmed, S. and Islam, M.T. (2014), "Electronic waste: present status and future perspectives of sustainable management practices in Malaysia”, Environmental Earth Sciences, Vol. 72 No. 7, pp. 2239-2249.

Sidique, S.F., Lupi, F. and Joshi, S.V. (2010), "The effects of behavior and attitudes on drop-off recycling activities", Resources, Conservation and Recycling, Vol. 54 No. 3, pp. 163-170.

Singh, M., Thind, P.S. and John, S. (2018), "Health risk assessment of the workers exposed to the heavy metals in e-waste recycling sites of Chandigarh and Ludhiana, Punjab, India", Chemosphere, Vol. 203, pp. 426-433.

Song, Q., Wang, Z. and Li, J. (2012), "Residents' behaviors, attitudes, and willingness to pay for recycling e-waste in Macau", Journal of Environmental Management, Vol. 106, pp. 8-16.

StEP (Solving the e-waste problem) (2018), available at: www.step-initiative.org/ (accessed 01 April 2018).

Stern, P.C., Dietz, T., Abel, T., Guagnano, G.A. and Kalof, L. (1999), "A value-belief-norm theory of support for social movements: the case of environmentalism", Human Ecology Review, pp. 81-97. 
EFCC 1,1

Tanskanen, P. (2013), "Management and recycling of electronic waste", Acta Materialia, Vol. 61 No. 3, pp. 1001-1011.

Tong, X., Wang, T., Chen, Y. and Wang, Y. (2018), "Towards an inclusive circular economy: quantifying the spatial flows of e-waste through the informal sector in China", Resources, Conservation and Recycling, Vol. 135, pp. 163-171.

Tonglet, M., Phillips, P.S. and Read, A.D. (2004), "Using the theory of planned behaviour to investigate the determinants of recycling behaviour: a case study from Brixworth, UK", Resources, Conservation and Recycling, Vol. 41 No. 3, pp. 191-214.

Van Liere, K.D. and Dunlap, R.E. (1981), "Environmental concern: Does it make a difference how it's measured?", Environment and Behavior, Vol. 13 No. 6, pp. 651-676.

Wan, C., Shen, G.Q. and Yu, A. (2014), "The moderating effect of perceived policy effectiveness on recycling intention", Journal of Environmental Psychology, Vol. 37, pp. 55-60.

Wang, C.Q., Wang, H., Fu, J.G. and Liu, Y.N. (2015), "Flotation separation of waste plastics for recycling-a review", Waste Management, Vol. 41, pp. 28-38.

Wang, Z., Guo, D. and Wang, X. (2016), "Determinants of residents'e-waste recycling behaviour intentions: evidence from China", Journal of Cleaner Production, Vol. 137, pp. 850-860.

Wang, Z., Zhang, B., Yin, J. and Zhang, X. (2011a), "Willingness and behavior towards e-waste recycling for residents in Beijing city", Journal of Cleaner Production, Vol. 19 Nos 9/10, pp. 977-984.

Wang, B., Ren, C., Dong, X., Zhang, B. and Wang, Z. (2019), "Determinants shaping willingness towards on-line recycling behaviour: an empirical study of household e-waste recycling in China", Resources, Conservation and Recycling, Vol. 143, pp. 218-225.

Wang, Y., Luo, C., Li, J., Yin, H., Li, X. and Zhang, G. (2011b), "Characterization of PBDEs in soils and vegetations near an e-waste recycling site in South China", Environmental Pollution, Vol. 159 No. 10, pp. 2443-2448.

Wilkinson, K.G., Brooks, R.B., Balmer, C., Halliwell, D., Palmowski, L., Issa, J.G., Jeyaseelan, S., Meehan, B. and Baskaran, K. (2007), "A survey of waste management practices in Victorian dairy factories", Australian Journal of Dairy Technology, Vol. 62 No. 3, p. 154.

Yazdanpanah, N. (2016), "CO 2 emission and structural characteristics of two calcareous soils amended with municipal solid waste and plant residue”, Solid Earth, Vol. 7 No. 1, pp. 105-114.

Yin, J., Wang, K., Yang, Y., Shen, D., Wang, M. and Mo, H. (2014), "Improving production of volatile fatty acids from food waste fermentation by hydrothermal pretreatment", Bioresource Technology, Vol. 171, pp. 323-329.

Yong, Y.S., Lim, Y.A. and Ilankoon, I.M.S.K. (2019), “An analysis of electronic waste management strategies and recycling operations in Malaysia: challenges and future prospects", Journal of Cleaner Production, Vol. 224, pp. 151-166.

Zeng, X., Yang, C., Chiang, J.F. and Li, J. (2017), "Innovating e-waste management: from macroscopic to microscopic scales", Science of the Total Environment, Vol. 575, pp. 1-5.

\section{Further reading}

Ajzen, I. and Madden, T.J. (1986), "Prediction of goal-directed behavior: attitudes, intentions, and perceived behavioral control", Journal of Experimental Social Psychology, Vol. 22 No. 5, pp. 453-474.

Asean-Up (2018), “6 free maps of Malaysia”, available at: https:/aseanup.com/free-maps-malaysia/ (accessed 22 January 2019).

Awasthi, M.K., Pandey, A.K., Bundela, P.S., Wong, J.W., Li, R. and Zhang, Z. (2016), "Co-composting of gelatin industry sludge combined with organic fraction of municipal solid waste and poultry waste employing zeolite mixed with enriched nitrifying bacterial consortium", Bioresource Technology, Vol. 213, pp. 181-189. 
Bagozzi, R.P. and Yi, Y. (1988), "On the evaluation of structural equation models", Journal of the Academy of Marketing Science, Vol. 16 No. 1, pp. 74-94.

Bazrbachi, A., Sidique, S.F., Shamsudin, M.N., Radam, A., Kaffashi, S. and Adam, S.U. (2017), "Willingness to pay to improve air quality: a study of private vehicle owners in Klang valley", Journal of Cleaner Production, Vol. 148, pp. 73-83.

Botetzagias, I., Dima, A.F. and Malesios, C. (2015), "Extending the theory of planned behavior in the context of recycling: the role of moral norms and of demographic predictors", Resources, Conservation and Recycling, Vol. 95, pp. 58-67.

Browne, M.W. and Cudeck, R. (1993), "Alternative ways of assessing model fit”, Sage Focus Editions, Vol. 154, pp. 136-136.

Bunnell, T., Barter, P.A. and Morshidi, S. (2002), "Kuala Lumpur metropolitan area: a globalizing cityregion”, Cities, Vol. 19 No. 5, pp. 357-370.

Chau, P.Y. and Hu, P.J.H. (2001), "Information technology acceptance by individual professionals: a model comparison approach", Decision Sciences, Vol. 32 No. 4, pp. 699-719.

Chin, W.W. (1998), "The partial least squares approach to structural equation modeling", Modern Methods for Business Research, Vol. 295 No. 2, pp. 295-336.

Chin, W.W., Gopal, A. and Salisbury, W.D. (1997), "Advancing the theory of adaptive structuration: the development of a scale to measure faithfulness of appropriation”, Information Systems Research, Vol. 8 No. 4, pp. 342-367.

Compeau, D., Higgins, C.A. and Huff, S. (1999), "Social cognitive theory and individual reactions to computing technology: a longitudinal study”, MIS Quarterly, Vol. 23 No. 2, pp. 145-158.

Davies, J., Foxall, G.R. and Pallister, J. (2002), "Beyond the intention-behaviour mythology: an integrated model of recycling", Marketing Theory, Vol. 2 No. 1, pp. 29-113.

Do Valle, P.O., Reis, E., Menezes, J. and Rebelo, E. (2004), "Behavioral determinants of household recycling participation: the Portuguese case", Environment and Behavior, Vol. 36 No. 4, pp. 505-540.

Fornell, C. and Larcker, D.F. (1981), Structural Equation Models with Unobservable Variables and Measurement Error: Algebra and Statistics, SAGE Publications, Los Angeles, CA.

Greaves, M., Zibarras, L.D. and Stride, C. (2013), "Using the theory of planned behavior to explore environmental behavioral intentions in the workplace", Journal of Environmental Psychology, Vol. 34, pp. 109-120.

Hair, J.F., Anderson, R.E., Tatham, R.L. and Black, W.C. (1998), Multivariate Data Analysis, 5th ed., Prentice-Hall International.

Hair, J.F., Jr, Black, W.C., Babin, B.J., Anderson, R.E. and Tatham, R.L. (2010), "SEM: an introduction", Multivariate Data Analysis: A Global Perspective, pp. 629-686.

Johari, A., Alkali, H., Hashim, H., Ahmed, S.I. and Mat, R. (2014), "Municipal solid waste management and potential revenue from recycling in Malaysia", Modern Applied Science, Vol. 8 No. 4, p. 37.

Khan, F., Ahmed, W. and Najmi, A. (2019), "Understanding consumers' behavior intentions towards dealing with the plastic waste: perspective of a developing country", Resources, Conservation and Recycling, Vol. 142, pp. 49-58.

Ludin, A.N.M., Yaakup, A., Bakar, S.Z.A., Maidin, A. and Ramle, L.H. (2006), "GIS and planning support system for Klang valley region, Malaysia”, Asia GIS 6th International Conference:'GIS in Asia: Think Global Act Local', Universiti Teknologi Malaysia, pp. 1-7.

Mee, S.P., Lee, V. and Baldwin, J.E. (2004), "Stille coupling made easier - the synergic effect of copper (I) salts and the fluoride ion", Angewandte Chemie International Chemie, Vol. 43 No. 9, pp. 1132-1136.

Nunnally, J. and Bernstein, I.H. (1994), Psychometric Theory, 3rd ed., McGrawHill, New York, NY.

Røpke, I. (1999), "The dynamics of willingness to consume”, Ecological Economics, Vol. 28 No. 3, pp. 399-420.

Analyzing the intention of the households

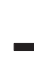


SPAD (2011), Greater Kuala Lumpur/Klang Valley Public Transport Master Plan, SPAD.

SPAD (2013), Land Public Transport Master Plan Greater Kuala Lumpur/Klang Valley, SPAD.

Sthiannopkao, S. and Wong, M.H. (2013), "Handling e-waste in developed and developing countries: initiatives, practices, and consequences", Science of the Total Environment, Vols 463/464, pp. 1147-1153.

Takahashi, V.O.K.V.M. (2005), "Establishment of global recycle network”, Fujitsu Scientific \& Technical Journal, Vol. 41 No. 2, pp. 242-250.

Tiep, H.S., Kin, T.D.Y., Ahmed, E.M. and Teck, L.C. (2015), "E-waste management practices of households in Melaka", International Journal of Environmental Science and Development, Vol. 6 No. 11, p. 811.

Vining, J. and Ebreo, A. (1992), "Predicting recycling behavior from global and specific environmental attitudes and changes in recycling opportunities 1”, Journal of Applied Social Psychology, Vol. 22 No. 20, pp. 1580-1607.

White, K.M. and Hyde, M.K. (2012), "The role of self-perceptions in the prediction of household recycling behavior in Australia", Environment and Behavior, Vol. 44 No. 6, pp. 785-799.

Yun, S., Vlachopoulos, N., Qurashi, A., Ahmad, S. and Hagfeldt, A. (2019), "Dye sensitized photoelectrolysis cells", Chemical Society Reviews, Vol. 48 No. 14, p. 3705.

Zen, I.S. and Siwar, C. (2015), "An analysis of household acceptance of curbside recycling scheme in Kuala Lumpur", Malaysia. Habitat International, Vol. 47, pp. 248-255.

\section{Corresponding author}

Rafia Afroz can be contacted at: rafia@iium.edu.my

For instructions on how to order reprints of this article, please visit our website: 